\section{Naum Trajanovski}

\section{A Review of the Partisan Counter-Archive: Retracing the Ruptures of Art and Memory in the Yugoslav Peo- ple's Liberation Struggle by Gal Kirn}

Gal Kirn, The Partisan Counter-Archive: Retracing the Ruptures of Art and Memory in the Yugoslav People's Liberation Struggle (Berlin - Boston: De Gruyter, 2020).

\begin{abstract}
Bionote: Naum Trajanovski (Graduate School for Social Research, Institute of Philosophy and Sociology, Polish Academy of Sciences) is a PhD candidate at the GSSR. He was a project co-coordinator at the European Network Remembrance and Solidarity (2017) and a researcher at the Faculty of Philosophy, Ss. Cyril and Methodius University - Skopje (2018-2020). His major academic interests include memory politics in North Macedonia and sociological knowledge transfer in 1960 sastern Europe. He authored several papers and a monograph, in Macedonian, on the memory politics in the state after 1991.
\end{abstract}

trajanovskinaum@gmail.com

Graduate School for Social Research, Institute of Philosophy and Sociology, Polish Academy of Sciences

The publishing of Gal Kirn's The Partisan Counter-Archive ${ }^{1}$ in mid2020 can be read in two particular keys: as the kernel of its author's decade-long investigation of "partisan, anticolonial and emancipatory memory/history of the past" ${ }^{\prime 2}$ - with a particular emphasis on the Yugoslav Partisan legacy in the Yugoslav and post-Yugoslav spaces - and one of the best critical archival scholarly takes on the impossibility of equating the opposing ideological positionings during wartime Yugoslavia, as well as equating the memory discourses stemming from these very positions; one of those everlasting debates in the region. Commencing with the latter, Kirn's

${ }^{1}$ Gal Kirn, The Partisan Counter-Archive: Retracing the Ruptures of Art and Memory in the Yugoslav People's Liberation Struggle (Berlin - Boston: De Gruyter, 2020).

${ }^{2}$ Gal Kirn, "Iconoclastic Ruptures: Black Lives Matter and the Cleansing of Colonial Memory," Pluto Press (June 2020), online. second monograph arrives in a moment when the memory studies scholarship on Yugoslavia and the post-Yugoslav states is unarguably more open to criticizing the ambivalence of various transnational actors (one such study is the recently edited volume on the Europeanisation and memory politics nexus in the Western Balkans $\left.^{3}\right)$, as well as the roles and agendas of nationalist and populist agencies in the memory struggles of the day. ${ }^{4}$ Here, Kirn's study not only provides an overview of the Yugoslav, and a detailed account of the Slovene developments, but also equips the reader with a solid theoretical and methodological arsenal for identifying the divergent set of claims, discourses and actors that antagonize the domains of public memory in the region and beyond. A scholar of cultural studies, philosophy and contemporary political theory himself, Kirn wrote significant scholarly pieces on the Yugoslav cinema, the Yugoslav Partisan memory sites and the market reforms in Yugoslavia and the post-Yugoslav states over the last years. His most recent work was recognized and received positive feedback relatively fast: so far, for instance, a symposium on the topic of "Counter Archive" was organized by the Institute for Cultural Inquiry Berlin in April this year, dedicated to Kirn's book and the German translation of Davor Konjukušić's Red Light: Yugoslav Partisan Photography and Social Movement (Rosa-Luxemburg-Stiftung, 2020), and a seminar on his book was organized by the Working Group on Post-Socialist and Comparative Memory Studies at the Memory Studies Organization in August, 2021.

The focal point of Kirn's analysis is the dissolution of Yugoslavia in the late 1980 s and the early 1990s, a process which unarguably shattered not only the political, economic and social, but also the symbolic realms of the states and citizens of formerYugoslavia. The new constellation of powers in the post-Yugoslav contexts thus paved the way for, what Kirn calls the, "ethnically cleansed point of view" over the national pasts and histories: a development pushed both by the emerging political elites in the former Yugoslav states and

${ }^{3}$ Ana Milošević and Tamara Trošt eds., Europeanisation and Memory Politics in the Western Balkans (London: Palgrave Macmillan, 2020).

4 See, for instance, Vjeran Pavlaković and Davor Pauković, eds., Framing the Nation and Collective Identities: Political Rituals and Cultural Memory of the Twentieth-Century Traumas in Croatia (London - New York: Routledge, 2019); Jelena Đureinović, The Politics of Memory of the Second World in Contemporary Serbia: Collaboration, Resistance and Retribution (London - New York: Routledge, 2020); and Jody Jensen, Memory Politics and Populism in Southeastern Europe (London-New York: Routledge, 2021) 
certain transnational actors. ${ }^{5} \mathrm{~A}$ particular target of these two agencies was, and still is, the Yugoslav Partisan legacy and the legacy of the People's Liberation Struggle (PLS). Kirn depicts this process as a "primitive accumulation of memory," that is, an operation of establishing new national canons via symbolic and even physical violence to the Partisan-related memory and memory sites, while simultaneously looking for what the historian Balázs Trencsényi observes as different "reservoirs" 6 for feeding the national ideologies: expanding to the pre-WWII state formations, via the medieval kingdoms to the ancient empires in the region. At this point, Kirn mentions, en passant, the case of the "antiquization"7 or "primordialization"8 in North Macedonia as a "climactic" among the other post-Yugoslav revisionisms of the socialist past (although, arguably enough, the rereading of the Macedonian socialist past over the previous decade best reflects the aggressiveness of the rightist political and memory actors in the state). Kirn sees these memory transitions as more important than the economic transitions in the region and beyond, and traces the origins of these revisionist discourses back to the initial conservative and neoliberal attacks on the welfare state model and the subsequent attempts to position the historical memory of the "two totalitarianisms" as a dominant framework for interpreting the European $20^{\text {th }}$ century history.

As a critical-theory-driven answer to the abovementioned, Kirn proposes a work on articulating, systematizing and nurturing a "Partisan counter-archive" - an all-Yugoslav, transnational depository of the revolutionary arts and politics which dwells well beyond the traditional frameworks of national and centralized archives; ${ }^{9}$ or a "construction site" which is to weaponize the fragments of the Partisan legacy and transfer them into the present and the future. ${ }^{10}$ The latter argument, as such, resonates both with the recent ap-

${ }^{5}$ Kirn, The Partisan Counter-Archive, 2.

${ }^{6}$ Balázs Trencsényi, "Beyond Liminality? The Kulturkampf of the Early 2000 s in East Central Europe," boundary, 2:41 (2014), 137.

${ }^{7}$ For an overview of the argument, see: Anastas Vangeli, "Nation-building ancient Macedonian style: the origins and the effects of the so-called antiquization in Macedonia," Nationalities

Papers, 39:1 (2011), 13-32.

${ }^{8}$ More in: Ognen Vangelov, "The Primordialisation of Ethnic Nationalism in Macedonia," Europe-Asia Studies, 71:2 (2019), 203-224

${ }_{9}^{9}$ Kirn, The Partisan Counter-Archive, 2-57.

${ }^{10} \mathrm{Gal}$ Kirn, "Dissonance of Yugoslav Partisan Past in the Recent Revisionist Methodologies," in Researching Yugoslavia and its Aftermath: Sources, Prejudices and Alternative Solutions, ed. by Branislav Radeljić and Carlos González-Villa (Cham: Springer, 2021), 42. propriation of Chantal Mouffe's agonism by memory scholars- in light of the proposed weaponization of certain episodes from the past in the present- as well as, to a lesser extent - the notion of "progressive nostalgia" from the Critical Heritage Studies. ${ }^{11}$ The Partisan counter-archive evolves around the other critical construct of Kirn's analysis: that of the "Partisan surplus." Inspired by the Derridian supplement and the "structuralist appropriation of the notion of surplus,"12 as well as Marx's notion of "surplus value" and Lacanian "surplus enjoyment," the Partisan surplus refers to the histories of the "revolutionary people" and the emancipatory programs for the future stemming from these very histories, while, simultaneously, its records resist political endorsements into official memory practices and politics. The book's structure thus mirrors the public reconsiderations of PLS - or what he observes, at another occasion, as the first of the three "Partisan ruptures"13 — in a diachrony of several decades. Chapter II starts with the WWII and PLS (1941-1945). Here, Kirn discusses the early Partisan artwork as means of cultural empowerment, symbolic armament and mobilization, as well as the most emblematic Partisan images and gestures of resistance. Swiping through the "curated selection" of the wartime poetry of Matej Bor, Karel Kajuh and Ivan Goran Kovačić, the iconic gestures of Stjepan Filipović and Lepa Radić, and Partisan posters, anthems, films and graphic arts, among the other records, Kirn argues that the Partisan artistic production is inseparable from the wartime struggle. Moreover, the wartime artwork showcases that this strive for freedom not only crossed out the ethnic boundaries of the Yugoslav Partisans, but also contributed to women's empowerment and emancipation, while avoiding to solidify as a centralized pattern or model, being mostly anonymous and collective, and even expanding. the limits of the certain pre-war artistic genres.

Chapter III deals with the attempts to materialize the wartime Partisan rupture in the post-WWIIYugoslavia of the 1960s and 1970s. Kirn,

\footnotetext{
${ }^{11}$ For an overview, see Anna Cento Bull and Hans Lauge Hanse, "On Agonistic Memory," Memory Studies, 9:4 (2016), 390-404; and Laurajane Smith and Gary Campbell, "'Nostalgia for the future': memory, nostalgia and the politics of class," International Journal of Heritage Studies, 23:7 (2017), 612-627.

${ }^{12}$ As depicted in the summary of his ICI research project "Suplement and Suprlus as Reduction(ism): Partisan Art and Archive" (2020-2021).

${ }^{13}$ Gal Kirn, Partisan Ruptures: Self-Management, Market Reform and the Spectre of Socialist Yugoslavia (London: Pluto Press, 2019). The other two ruptures being the self-management and the Non-Aligned Movement.
} 
here, focuses on the Yugoslav films portraying PLS (Partisan films) - between 1945-1985, more than 200 Partisan films were produced in Yugoslavia - and the movement to create "monuments to revolution" - several thousands of them being erected over the same period. Faced with this "impossible task," ers and sculptors developed aesthetic languages which were both open to appropriation from the officials and, parallelly, left space for disagreements with the official political discourses. The analysis of the rationale behind the formation and the afterlives of Tjenište (1971) and Kozara (1972) memorial sites, two monuments to the revolution, revealed certain patterns of the Yugoslav "socialist monumental modernism"; a lack of a manifesto; bottom-up incentives for their establishments; and, finally, their authors' common endeavor to "commemorate something that does not want to seal political power forever, something inscribed in the utopian emancipatory horizon of the future. ${ }^{15} \mathrm{~A}$ similar finding can be observed in another recent publication in Macedonian, Elena Čemerska's Spomenik na slobodata: Razgovornik, which presents a set of expert interviews related to the formation and the cultural meaning of the memorial complex "Monument to freedom" (1981) in Kočani. ${ }^{16}$ Čemerska's work is one of the rare Macedonian counter-archival exercises in this regard: the focus on the memorial complex - built on the occasion of the $40^{\text {th }}$ anniversary of the Macedonian struggle for freedom was depicted not as a mere nostalgic move, but rather as an engaging approach to the "unfinished past" which revealed, among other things, that the Macedonian cultural policies of the $1970 \mathrm{~s}$ and the early 1980 s were much more democratic and transparent than assumed today (a point which can also be juxtaposed with the cultural and memory politics in the $2010 \mathrm{~s}$ in Macedonia). ${ }^{17}$ In this chapter, Kirn also proposes a closer look at the Yugoslav cinematic production in the 1960 s and 1970s: although the authorities almost immediately incorporated the film industry as a tool for solidifying a PLS narrative and, as such, legitimizing their political generation, the Partisan film genre also presented a platform for twisting the official narratives over history and memory (Kirn discusses Želimir

${ }_{14}$ See, as well, Gal Kirn, "On the Specific (In)existence of the Partisan Film in Yugoslavia's

People's Liberation Struggle," in Partisans in Yugoslavia: Literature, Film and Visual Culture, ed. by Miranda Jakiša and Nikica Gilić (Bielefeld: Transcript, 2015).

${ }^{15}$ Kirn, The Partisan Counter-Archive, 194.

${ }^{16}$ See: Elena Čemerska, Spomenik na slobodata: Razgovornik (Skopje: Privateprint, 2019).

${ }^{17}$ Ibid., 20-21.
Žilnik and Miodrag Popović, while one possible Macedonian case for analysis, here, might be Kiril (enevski's Jad).

Finally, Chapter IV is focused on the process of undoing the Partisan counter-archive across the post-Yugoslav space, in general, and Slovenia, in particular. Kirn writes about it in a clear and direct manner. The elite-driven attempts to revise the Partisan legacy (in Slovenia, as of the 1980s) are part of the same mnemonic maneuver that unfolds in several ways: the physical destruction of the Yugoslav memory sites and their transformation in religious memory sites, as well as via an operation of national reconciliation, epitomized in the memorial complex for the killed Home Guards at Kočevski Rog and the Monument to the Victims of All Wars in Ljubljana; an open rehabilitation of local fascism, such as the case of the Monument of the Silent Victims in Grahovo, and, finally; the promotion of the discourse of anti-totalitarianism, such as the project for the Pan-European Memorial to the Victims of Totalitarian Crimes which is to be located in Brussels. Here, Kirn argues that these memory sites present a platform for performing "commemorative revisionism" — that is, a process of shifting the mnemonic canons by watering down the ideological and political backgrounds and motives of the perpetrators. This chapter, however, is focused primarily on Slovenia, which trod a different path of post-Yugoslav state consolidation; although relevant for all the other former Yugoslav states with all of their specificities and particularities. It is immensely important, moreover, for the Macedonian public as the PLS — which was a formative event, as well, for the Macedonian state and nation-building - undergoes some of the prevailing revisionist attacks mapped by Kirn; instigated by national and international actors. ${ }^{18}$ One possible counter-archival response, here, would spring from a critical rereading of the basic values of PLS in Macedonia and its implications over the social and political emancipation in the state. Kirn's book provides a decent tool for further analyses in these regards.

${ }^{18}$ For an overview, see Naum Trajanovski, Operacijata Muzej: Muzejot na makedonskata borba $i$ makedonskata politika na sekjavanje (Skopje: Templum, 2020). 